UDC 352:316.776.3

JEL classification: F020; H790; M140; 1140; 0190

\title{
REPUTATION CAPITAL AS THE FACTOR OF COMPETITIVE RECOVERY OF UKRAINIAN ENTERPRISES ON THE INTERNATIONAL MARKET
}

\author{
O. O. Baliun, S. B. Fiialka \\ National Technical University of Ukraine «Igor Sikorsky Kyiv Polytechnic Institute», \\ 1/37, Yangel St., Kyiv, 03056, Ukraine
}

Introduction. In today's market economy, business reputation is becoming a key factor of business competitiveness and the most effective means of promotion, investment and customers attraction. However, in Ukraine the reputation is still not considered as a strategic resource of confidence to the state both among internal and external audiences. The aim of the article is to identify the factors that affect adversely the reputation of Ukrainian enterprises and to prove the necessity to create positive reputation of Ukrainian business, as an important component towards its integration into the world economic space.

Conclusions. In this study, we have suggested to consider the reputation of Ukrainian enterprises by the cyclic multi-level system of forming the reputation: reputation of the state - reputation of the region - reputation of the district - reputation of the areareputation of settlements - reputation of the company - reputation of the state. The interference and interconnection of reputation of the state and a single enterprise has been confirmed by the analysis of Ukraine's positions in key world rankings and the discourse analysis of texts written by the representatives of global financial and international institutions operating in Ukraine. The study defines the negative factors, which affect the reputation of both the state and Ukrainian enterprises. Thus, the formation of reputational economy should become the basis for the implementation of new economic paradigm in Ukraine. The reputation capital should be a major asset in shaping the competitive advantages of Ukrainian business on the international market.

Keywords: reputation, corporate reputation, public administration, investment, competitiveness, rankings.

Formulation of the problem. Technological innovations of the late 20th and beginning of the 21 st centuries, particularly in the information and communication industry have become one of the factors in the global transformation of social and economic models of human activity. One of the major achievements that influenced significantly the development of macroeconomic science is the comprehension of how important the role of reputation is in the state economic policy.

The integration of Ukrainian business in the world economy is not possible without the positive reputation of both the state and the business itself. A global challenge Ukraine faces with is the creation of long-term program of the formation of the state positive 
image, the implementation of which will allow: to accelerate the integration process of Ukrainian enterprises into the global economy and boost their competitiveness, increase internal and external investments of the national economy. An issue of the same importance is to form the awareness in Ukrainian business about all the levels of the necessity of continuous work directing at the establishment of a positive corporate reputation.

Analysis of recent researches and publications. Among foreign researchers of business reputation problems and corporate image, there are such prominent scientists as A.Griffin (2008) [1]; G. Dowling (2002) [2]; B.King (2012) [3]. In their writings, these experts define the basic concepts, characteristics, methods and techniques of corporate reputation forming, the criteria for assessing its effectiveness.

The studies of reputation as the object of economic management have become one of the essential problems in economics; they were described in the works of C. Shapiro (1983) [4], K. Weight, and C. Camerer (1988) [5]. In terms of strategic reputation management, a special attention should be paid to the studies of C. Fombrun, C. Van Riel (2007) [6], C. Fombrun and M. Shanley [7].

The studies of Nobel laureates Finn E.Kydlandr and Edward C. Prescott (1990) have become very significant for further study and generalization of foreign experience for the purpose of practical application in Ukraine [8]. Among experts, they are called «the theory of reputation.» The scientists stated that the problem of reputation loss should be considered as the problem of temporal inconsistency of economic policy conduct, the consequence of which is high inflation, the collapse of the economy, lack of confidence among investors and its own population. Finn E.Kydlandr and Edward C. Prescott believe that the state must have the reputation of the supporter of low inflation and also be independent of current political situation. The notion of reputation management is quite new for Ukrainian specialists and almost unexplored. The studies of Ukrainian scientists are mainly devoted to the analysis and generalization of foreign experience in the formation and management of corporate reputation, for example, such experts as T. Fedoriv (2012) [9] and K. Scherbakova (2010) [10].

Therefore, the task of creating one's own theoretical and methodological research staff and reputation management has become particularly relevant. One of the first such works is the study of A.Kashpur (2015) [11], who suggested an author's technique of triad retrospective scripting (TRScr) as a forecasting tool which makes it possible to find out and describe the plausible scenarios of the changes of great social systems from the position of the designer that is located in the expected future.

The purpose of this article is to identify the factors that adversely affect the reputation of Ukrainian enterprises and to ground the necessity of forming the positive reputation of Ukrainian business, as an important component towards its integration into the world economic space.

Research results. Until recently, business success could be determined only by the level of its profitability, but nowadays the representatives of international companies, authoritative international economic institutions indicate that the reputation is the most effective means of promotion, investment and customer attraction. In particular, due to 
the studies of Environics International, a Canadian research company, positive business reputation is crucial for investors' decisions. The decisions on the investment are made on the basis of financial indicators provided the company's reputation is positive [12]. The practical evidence of this conclusion is a clear rationale of the main criteria concerning a positive decision to invest in the Ukrainian company, made by a EBRD Director in Ukraine Sh.Adzhuner. In particular, there are such criteria as high reputation and a good credit history [13].

Under Ukrainian conditions of hybrid war, corrupt authorities, unstable economy, the state must act as the main driving force in promoting a positive business reputation of its domestic enterprises. Above all, the state must create credibility and demonstrate the ability to develop and strengthen its economic potential.

Thereupon it is worth considering the role of reputation in public administration both from the viewpoint of understanding the role of this important resource by civil servants and on the legislative level as the legal bases of reputational culture formation. Nowadays, Ukrainian higher state authorities have not formed a sufficient awareness that in order to increase investment attractiveness and therefore, to integrate into the global business environment, it is necessary to begin with the creation of the country's positive image. This argument is confirmed by the analysis of texts of official statements made by the representatives of Ukrainian government institutions regarding the necessity to change the vision of Ukraine the international community has. The official rhetoric mostly concerned Ukrainian "image strengthening", "image improvement", "image promotion" in the world. The term «reputation» is hardly used in the state-political lexicon.

Having analyzed the official documents relating to state informational, economic, and investment policy, we noticed that they do not contain the term "reputation" either. The main document of the state "Sustainable Development Strategy "Ukraine-2020", which defines the main directions and priorities of the country's development, indicates that the key objective of the Program of popularization of Ukraine in the world and promotion of Ukrainian interests in the global informational space should be the creation of a positive image of Ukraine as a European, democratic, competitive state with the favorable business climate [14].

Another document of equal importance "The concept of popularization of Ukraine in the world and the promotion of Ukrainian interests in the global information space" included the term "reputation" in the process of its development but later on, during the approval stage it was replaced by the term "image". Thus, the Concept emphasized the need for strengthening the image of Ukraine as a reliable business partner, the state, wih the rich history, culture, significant industrial, export, tourist, and investment potential [15].

Thus, both Strategy and Concept define a solely tactical task - to create the image, and never developed a strategic task - to build the reputation of the state through its image formation.

It should also be noted that one of important issues on the legislation level of Ukraine is the lack of accurate definition of such notion as business reputation, as it is considered through the prism of moral and ethical category, and the law regards it as 
an independent object of judicial protection. Therefore, the problem of protecting the business reputation of the legal entity is still relevant for improving current civil law.

As regards the estimated value of business reputation - the concept of "goodwill" according to p.14.1.40 of the Tax Code of Ukraine it is defined as an intangible asset the value of which is determined as the difference between the market price and the carrying amount of enterprise assets as an integral property complex, resulting from the use of the best management qualities, dominant position on the market of goods, services, new technologies, etc. [16].

However, other regulations, particularly the Regulations (Standard) of accounting report \#8 "Intangible Assets" and the Law of Ukraine "On taxation of corporate income" also include the regulations that classify and regulate intangible assets. These definitions are interpreted ambiguously, they are rather contradictory, leading not only to legal and administrative difficulties, but sometimes to unfair competition and reputational risks. That is why, Ukraine uses two different approaches to the definition and classification of intangible assets simultaneously: domestic regulations of accounting report and International Financial Reporting Standarts (IFRS). Such legal difficulties lead to the fact that many Ukrainian companies working with foreign partners, are forced to keep three different reports at the same time - accounting and tax reports due to Ukrainian standards and also financial one - due to international standards [17].

Ukraine has obviously just started creating its reputation management. It is going to work a lot in this direction in order to form the understanding of its necessity and create adequate legal conditions.

We consider that under Ukrainian realities, the algorithm of business reputation of the companies which intend to enter the overseas market or attract foreign investment, is formed by the following cyclic multi-level system: the reputation of the state - the reputation of the region - the reputation of the district - the reputation of the area - the reputation of settlements - the reputation of the company - the reputation of the state. The reputation of the state is the first starting point towards the integration into global business environment which attracts the attention of potential partners and investors.

In order to clarify the existing reputation of Ukraine in the world, we have analyzed the indicators of our country in global world rankings. For the study, we have chosen the rankings reflecting the main indicators that attract potential business partners for the expansion of business relations in the context of business globalizaton and internationalization (see Table 1).

Due to a key ranking for our survey, The Country RepTrak, during 2012-2014, Ukraine was attributed to the group of countries with a weak reputation but since 2015 it began to lose its positions and in 2016, moved to the ranking of countries with a bad reputation, taking 59th place (out of 70 countries). The ranking is based on a complex ananlysis system developed by Reputation Institute and RepTrak System reputation management. For the assessment, four main categories were identified: esteem, admire, trust, feeling. Each of them, in its turn, is subdivided into 16 indicators including such parameters as the quality of life, foreign policy, business climate, goods and services, infrastructure, natural beauty, and tourist attraction. 


\begin{tabular}{|c|c|c|c|c|c|c|c|}
\hline \multirow{2}{*}{ Ranking } & \multirow{2}{*}{ Indicator } & \multicolumn{6}{|c|}{ Place of Ukraine } \\
\hline & & 2012 & 2013 & 2014 & 2015 & 2016 & 2017 \\
\hline $\begin{array}{l}\text { The } \\
\text { Country } \\
\text { RepTrak }\end{array}$ & $\begin{array}{l}\text { Esteem } \\
\text { Admire } \\
\text { Trust } \\
\text { Feeling }\end{array}$ & 42 & 42 & 42 & 47 & 59 & 45 \\
\hline $\begin{array}{l}\text { The City } \\
\text { RepTrak }\end{array}$ & $\begin{array}{l}\text { Esteem } \\
\text { Admire } \\
\text { Trust } \\
\text { Feeling }\end{array}$ & 73 & 73 & 90 & 94 & - & - \\
\hline $\begin{array}{l}\text { Doing } \\
\text { Business }\end{array}$ & $\begin{array}{l}\text { Starting a business } \\
\text { Dealing with construction Per- } \\
\text { mits getting electricity } \\
\text { Registering property } \\
\text { Getting credit } \\
\text { Protecting minority investors } \\
\text { Paying taxes } \\
\text { Trading across borders } \\
\text { Enforcing contracts } \\
\text { Resolving insolvency }\end{array}$ & 152 & 137 & 112 & 87 & 83 & 80 \\
\hline $\begin{array}{l}\text { Index of } \\
\text { Economic } \\
\text { Freedom }\end{array}$ & $\begin{array}{l}\text { Property rights } \\
\text { Judicial effectiveness } \\
\text { Government integrity } \\
\text { Tax burden } \\
\text { Government spending } \\
\text { Fiscal health } \\
\text { Business freedom } \\
\text { labor freedom } \\
\text { Monetary freedom } \\
\text { Trade freedom } \\
\text { Investment freedom } \\
\text { Financial freedom }\end{array}$ & 163 & 161 & 155 & 162 & 162 & 166 \\
\hline $\begin{array}{l}\text { The Global } \\
\text { Enabling } \\
\text { Trade } \\
\text { Index }\end{array}$ & $\begin{array}{l}\text { Market access } \\
\text { Border administration } \\
\text { Infrastructure } \\
\text { Operating environment. }\end{array}$ & 86 & - & 83 & - & 95 & - \\
\hline $\begin{array}{l}\text { The Rule } \\
\text { of Law } \\
\text { Index }\end{array}$ & $\begin{array}{l}\text { Constraints on Government } \\
\text { Powers } \\
\text { Absence of Corruption } \\
\text { Open Government } \\
\text { Fundamental Rights } \\
\text { Order and Security } \\
\text { Regulatory Enforcement } \\
\text { Civil Justice } \\
\text { Criminal Justice } \\
\end{array}$ & 80 & 87 & 68 & 70 & 76 & 77 \\
\hline
\end{tabular}




\begin{tabular}{|l|l|l|l|l|l|l|l|}
\hline $\begin{array}{l}\text { The Cor- } \\
\text { ruption } \\
\begin{array}{l}\text { Perceptions } \\
\text { Index }\end{array}\end{array}$ & $\begin{array}{l}\text { The index is compiled on the } \\
\text { basis of } 13 \text { studies of indepen- } \\
\text { dent international organiza- } \\
\text { tions, which conduct a survey } \\
\text { of businessmen and analysts in } \\
\text { various countries }\end{array}$ & 144 & 144 & 142 & 130 & 131 & 130 \\
\hline
\end{tabular}

Source: Compiled by the authors based at [18-24]

Reputation Institute, the developer of the study, states that reputation has a direct impact on the state welfare and its ability to compete and thrive in the global economy, which is of paramount importance under conditions of stiff competition for investment attraction, trade and tourism development.

But if The Country RepTrak takes into account the political component in determining the ranking of the country, the Doing Business ranking (it is made by the World Bank together with the International Financial Corporation) regards exclusively the conditions of organization and business administration on the level of state regulation. Although Ukraine has risen by 69 positions since 2012, it is still mainly considered as the country with opaque and inefficient norms of business regulation, where an access to business opportunities depends on personal connections and corruptional schemes.

This reputation of Ukraine is confirmed by such rankings as Index of Economic Freedom, The Rule of Law Index, The Corruption Perceptions Index, where it is still firmly holds the position of the most corrupt European country as well as the state with an unfree economy. An example, describing not only theoretical but also practical side of the study subject may be the scandalous situations of the oppression of foreign investors in Ukraine, in particular, a French winemaker K.Lakaren in Shabo village of Odessa region, a Danish investor Soren Peter Schmidt of "AKAHT + K" in Cherkasy region, an Austrian investor H. Cegetmayer, representative of the IMMOFINANZ Group.

In order to identify the most problematic causes of the competitiveness of Ukrainian goods and services and, hence, the reputational risks on the global markets, we have analyzed The Global Enabling Trade Index data. The study has shown that the problematic factors for export are the following: identifying potential markets and buyers, difficulties in meeting quality / quantity requirements of buyers, access to trade finance, technical requirements and standards abroad, inappropriate production technology and skills [22]. The data of this ranking can serve Ukrainian businessmen as important coordinates for becoming a reliable, competitive trading partner with a positive business reputation.

On a global scale, the ranking of administrative-territorial units of Ukraine depends directly on the whole ranking of the state. Therefore, nowadays, the considered positions of Ukraine in the world rankings directly affect the reputation of the regions, districts, provinces, and settlements. But an example, which we can take for better understanding the reputation of Ukrainian territorial unit, is The City RepTrak ranking, where the capital of Ukraine Kyiv is included. This ranking shows what cities are the most attractive for visiting, living, working, investing, and shopping. In 2012-2015, the Ukrainian capital was almost on the last positions, and in 2016, it fell out of tha ranking. However, it should be noted that the loss of positions in 2016 is caused by the fact that the Institute 
of reputation changed the sampling and the ranking consisted not of 100 cities, as it was in the previous years, but of 55 .

The conducted analysis of Ukraine's position in the key rankings, affecting its reputation suggests that further integration of domestic enterprises into the global economic environment, attracting foreign investments and loans is faced with the feeling of country risk the potential investors and partners have regarding our country.

To our mind, the negative reputation of our country is not so much due to the armed conflict in eastern Ukraine as to the corruption, bureaucracy, problems with the protection of property rights, work permits and temporary stay in the country, difficulties with capital repatriation.

Potential foreign partners are expecting changes both in legislation and in the actions of the executive authority. The changes must concern first of all the anticorruption drive, simplification of doing business, taxation system, etc. Correspondingly investments will increase after the appearance of "happy stories" about the investors who work successfully on Ukrainian market, i.e. when one can state that the reputation of economic and business climate in the country has begun to improve.

Following the suggested multi-level system of forming the reputation of Ukrainian business, let us consider the main requirements for the last component of this system the reputation of companies. Nowadays, the authoritative world research institutions that form ranking evaluation systems in various areas, including the Reputation Institute, do not conduct systematic research of business reputation of Ukrainian companies and do not publish the results of the studies which are carried out at the request of separate businesses.

Some Ukrainian scientific research institutions have tried to assess the reputation of the domestic business in certain spheres, including banking area and agrarian sector. However, studies were conducted occasionally, and yet their quality is questionable. Thus, in our study, we cannot use the ranking system of Ukrainian business assessment and use its results for determining negative influence.

In this connection, we have selected a representative group of key people (interviewers), the representatives of global financial and international institutions. The group formulated basic requirements for the business reputation of Ukrainian enterprises. Through the discourse analysis, we have identified basic internal and external risk factors of business reputation loss, which are typical for Ukrainian business environment only. The representative group consisted of the representatives from IFC, EBRD, the American Chamber of Commerce in Ukraine, PricewaterhouseCoopers consulting company, Chamber of Commerce and industry in Ukraine, and ICU investment group [13, 25-29].

So, according to our analysis, we have identified the following factors that undermine the confidence of international financial, investment institutions and partners, and also call forth the risk of business reputation loss: political or authoritative support; support of criminal groupings; participation in corrupt schemes; difficulties in explaining the appearance of initial capital; inability to explain the history of asset privatization; monopolistic position on the market and / or cases of unfair competition; lack of prospects of the company and the market in general; authoritarian company management; failure to comply with international business ethics; ecological violations. 
In its turn, the main indicators of good business reputation of Ukrainian enterprises should be the following: transparent structure of ownership, financial reporting, corporate governance; corporate social responsibility (CSR); compliance of real actions to mission and values declared by a company; transparency in providing public information; compliance with labor legislation; positive credit and investment history; keeping the duties to pay taxes; compliance with Ukrainian legislation; reputation of the company's owner and the company itself; positive reputation in the media, especially international ones.

Thus, we can conclude that for potential international investors and partners, the investment and business attractiveness of Ukrainian enterprises depends on the presence of their positive corporate reputation.

The main problem of most Ukrainian enterprises is the lack of understanding how necessary it is to work constantly on the formation of corporate reputation. Typically a Ukrainian entrepreneur (SME) neither understands the difference between the image and reputation, nor considers it necessary to invest minimum resources into formation of a positive perception of the company by the key stakeholders of his/her company.

It should be emphasized that the reputation of the state, its territorial-administrative units and individual companies are interrelated. On the one hand, the state reputation both in the world and among its citizens affects business development and success. On the other hand, the reputation of individual companies makes up the reputation of the country. That is why a common practice among Ukrainian businesses is finding the ways to avoid the negative impact the brand "Ukraine" bears. In particular, the domestic companies who intend to enter or have already entered the international market, position themselves as European companies by changing the registration of the company in the offshore zone. So, some Ukrainian goods enter foreign markets under a different brand name and source nature. Thus, there appears a vicious circle: the country's bad reputation undermines the quality of domestic business, which, in its turn, leaves the country and aggravates its reputation.

Hence there comes practical conclusion that Ukraine needs a new economic paradigm, which should be based on the formation of reputational economy. This process will be long, since mentioned above consequences of the whole range of negative factors that affected and still affect the reputation of Ukraine, will have to be renewed from scratch. In particular, it is of urgent importance to regulate legally the provisions relating to the definition of the very concept "business reputation" and the estimated value of intangible assets (goodwill); to create awareness both on the levels of public administration and businessmen that it is necessary to create a sustainable approbatory reputational capital; to continue making consistent and clear economic, legislative, and administrative reforms. Building a positive reputation must become a major subject of business strategy. Under conditions of modern market economy the reputation should become a key factor in business competitiveness.

Conclusions. The problem of the formation, development and protection of business reputation is of current importance both on the level of public administration and on the level of Ukrainian business. The study has shown the relationship and mutual influence of the reputation of the state and reputation of a single enterprise. This fact allows us to 
talk about the recurrence of a multilevel system of reputation: reputation of the state reputation of the region - reputation of the district - reputation of the area - reputation of settlements - reputation of the company - reputation of the state.

The negative factors that affect the reputation of Ukrainian enterprises and prevent domestic business from integrating into the global business are opaque and inefficient norms of business regulation; bureaucracy; corruption; lack of understanding by business the threats of reputational risks and how important it is to develop its own business reputational capital.

The formation of positive reputation of Ukrainian business on the global market should begin with the understanding of its strategic role on the state level. The result of successive economic, legislative and administrative reforms should become a revival of confidence to the state on the part of potential investors and partners, as well as Ukrainian businessmen. Then the business reputation of Ukrainian companies will form into a strong export potential and investment attractive business that ultimately will lead to the creation of reputational economy.

Further studies. Given the scientific and practical importance to research fully the technologies of creating and managing corporate reputation as well as their implementation in Ukrainian practice, all the elements of reputation management require further study. It will allow us to develop the algorithms of reputation management, typical to the mentality of Ukrainian market.

\section{СПИСОК ВИКОРИСТАНИХ ДЖЕРЕЛ}

1. Griffin A. New Strategies for Reputation Management: Gaining Control of Issues, Crises and Corporate Social Responsibility. London: Kogan Page, 2008. 176 p.

2. Dowling G. Creating Corporate Reputations: Identity, Image, and Performance. London: Oxford University Press, 2002. 320 p.

3. King B., McDonnell M-H. Good firms, good targets: The relationship between corporate social responsibility, reputation, and activist targeting. 2012. URL: http://ssrn.com/abstract= 2079227.

4. Shapiro C. Premiums for High Quality Products as Returns to Reputations. The Quarterly Journal of Economics. 1983. Vol. 98, No. 4 (Nov., 1983). Pp. 659-680.

5. Weight K., Camerer C. Reputation and corporate strategy: a review of recent theory and applications. Strategic management Journal. 1988. Vol. 9. Pp. 443-454.

6. Van Riel Cees B. M., Fombrun C. J. Essentials of corporate communication: Implementing practices for effective reputation management. 2007. $328 \mathrm{c}$.

7. Fombrun C. J., Shanley M. What's in a name? Reputation building and corporate strategy. Academy of Management Journal. 1990. Vol. 33 (2). Pp. 233-258.

8. Kydland Finn E., Prescott Edward C. Business cycles: real facts and a monetary myth. Quarterly Review, Federal Reserve Bank of Minneapolis. 1990. issue Spr. Pp. 3-18.

9. Федорів Т. В. Інтерпретація поняття «репутація» у зарубіжних суспільствознавчих дослідженнях. Економіка та держава. 2012. № 7. С. 92-95.

10. Щербакова К. Ділова репутація як складова конкурентоспроможності підприємства. Економіка. 2010. № 2. С. 58-63.

11. Кашпур А. Репутация. Київ: Логос, 2015. 70 c. 
12. Hohnen P. Corporate Social Responsibility An Implementation Guide for Business. International Institute for Sustainable Development. 2007. URL: http://www.iisd.org/pdf/2007/ csr_guide.pdf.

13. ФПГ - это фундаментальная часть экономики, которая никуда не денется - директор ЕБРР в Украине. Дело.uа. 9 грудня 2016. URL: https://delo.ua/business/fpgeto-fundamentalnaja-chast-ekonomiki-kotoraja-nikuda-ne-den-326040/?supdated_new= 1495731568.

14. Про Стратегію сталого розвитку «Україна - 2020»: Указ Президента України від 12.01.2015 № 5/2015. URL: http://zakon2.rada.gov.ua/laws/show/5/2015.

15. Концепція популяризації України у світі та просування інтересів України у світовому інформаційному просторі: розпорядження Кабінету Міністрів України від 11 жовтня 2016 p. № 739-p. URL: http://zakon2.rada.gov.ua/laws/show/739-2016-\%D1\%80.

16. Податковий кодекс України від 2 грудня 2010 року: зі змінами станом на 24 листопада 2011 року. URL: http://zakon3.rada.gov.ua/laws/show/2755-17.

17. Бєліков О. Гудвіл, як складова частина нематеріальних активів. Юридичний журнал. 2009. URL: http://www.justinian.com.ua/article.php?id=3217.

18. Previous country reptrak reports. 2016. URL: https://www.reputationinstitute.com/thoughtleadership/country-reptrak.

19. Past City RepTrak® Results. 2016. URL: https://www.reputationinstitute.com/research/CityRepTrak.aspx.

20. Doing Business. 2017. URL: http://www.doingbusiness.org/reports/global-reports/doing-business-2017.

21. Index of Economic Freedom. 2017. URL: http://www.heritage.org/index/ranking.

22. The Global Enabling Trade Index. 2016. URL: https://www.weforum.org/reports.

23. The Rule of Law Index. 2016. URL: https://worldjusticeproject.org/our-work/wjp-rule-lawindex.

24. The Corruption Perceptions Index 2016. URL: https://www.transparency.org/news/feature/ corruption_perceptions_index_2016.

25. После кризиса собственники большого бизнеса сильнее вовлечены в операционную деятельность компании — глава PwC. delo.ua. 2016. URL: https://delo.ua/business/posle-krizisasobstvenniki-bolshogo-biznesa-silnee-vovlecheny-v-326478/?supdated_new=1495731568.

26. Імідж України в світі дуже спотворений — голова Американської торгової палати. delo. ua. 2016. URL: https://delo.ua/business/v-ukrajini-zminjujetsja-stavlennja-do-biznesu-golova-amerikansko-327602/?supdated_new $=1495731567$.

27. Из репутаций отдельных компаний складывается репутация страны - глава МФК в Украине. delo.ua. 2016. URL: https://delo.ua/business/iz-reputacij-otdelnyh-kompanij-skladyvaetsja-reputacija-strany-326172/?supdated_new=1496754960.

28. Чем крупнее бизнес, тем сильнее его потребность в положительной репутации, представитель ICU Александр Мартыненко. delo.ua. 2016. URL: https://delo.ua/business/ aleksandr-martynenko-326458/?supdated_new=1495585822.

29. Если мы создадим условия для внутренних инвесторов, внешние придут сами - президент ТПП. delo.ua. 2016. URL: https://delo.ua/business/ni-odna-agrarnaja-strana-ne-stanovilas-konkurentosposobnoj-gen-326620/?supdated_new=1496754612. 


\section{REFERENCES}

1. Griffin, A. (2008). New Strategies for Reputation Management: Gaining Control of Issues, Crises and Corporate Social Responsibility. London: Kogan Page (in English).

2. Dowling, G. (2002). Creating Corporate Reputations: Identity, Image, and Performance. London: Oxford University Press (in English).

3. King, B., \& McDonnell, M-H. (2012). Good firms, good targets: The relationship between corporate social responsibility, reputation, and activist targeting. Retrieved from http://ssrn. com/abstract=2079227 (in English).

4. Shapiro, C. (1983). Premiums for High Quality Products as Returns to Reputations: The Quarterly Journal of Economics, Vol. 98, 4 (Nov., 1983), 659-680 (in English).

5. Weight, K., \& Camerer, C. (1988). Reputation and corporate strategy: a review of recent theory and applications: Strategic management Journal, 9, 443-454 (in English).

6. Van Riel Cees, B. M., \& Fombrun, C. J. (2007). Essentials of corporate communication: Implementing practices for effective reputation management (in English).

7. Fombrun, C. J., \& Shanley, M. (1990). What's in a name? Reputation building and corporate strategy: Academy of Management Journal, Vol. 33 (2), 233-258 (in English).

8. Kydland, Finn E., \& Prescott, Edward C. (1990). Business cycles: real facts and a monetary myth: Quarterly Review, Federal Reserve Bank of Minneapolis. issue Spr., 3-18 (in English).

9. Fedoriv, T. V. (2012). Interpretatsiia poniattia «reputatsiia» u zarubizhnykh suspilstvoznavchykh doslidzhenniakh: Ekonomika ta derzhava, 7, 92-95 (in Ukrainian).

10. Shcherbakova, K. (2010). Dilova reputatsiia yak skladova konkurentospromozhnosti pidpryiemstva: Ekonomika, 2, 58-63 (in Ukrainian).

11. Kashpur, A. (2015). Reputatsyia. Kyiv: Lohos (in Ukrainian).

12. Hohnen, P. (2007). Corporate Social Responsibility An Implementation Guide for Business: International Institute for Sustainable Development. Retrieved from http:/www.iisd.org/ pdf/2007/csr_guide.pdf (in English).

13. FPG - eto fundamentalnaia chast ekonomiki, kotoraia nikuda ne denetsia — direktor EBRR v Ukraine: delo.ua. 9 grudnia 2016. Retrieved from https://delo.ua/business/fpg-eto-fundamentalnaja-chast-ekonomiki-kotoraja-nikuda-ne-den-326040/?supdated_new=1495731568 (in Russian).

14. Pro Stratehiiu staloho rozvytku «Ukraina - 2020»: Ukaz Prezydenta Ukrainy vid 12.01.2015 № 5/2015. Retrieved from http://zakon2.rada.gov.ua/laws/show/5/2015 (in Ukrainian).

15. Kontseptsiia populiaryzatsii Ukrainy u sviti ta prosuvannia interesiv Ukrainy u svitovomu informatsiinomu prostori: rozporiadzhennia Kabinetu Ministriv Ukrainy vid 11 zhovtnia 2016 r. № 739-r. Retrieved from http://zakon2.rada.gov.ua/laws/show/739-2016-\%D1\%80 (in Ukrainian).

16. Podatkovyi kodeks Ukrainy vid 2 hrudnia 2010 roku: zi zminamy stanom na 24 lystopada 2011 roku. Retrieved from http://zakon3.rada.gov.ua/laws/show/2755-17 (in Ukrainian).

17. Bielikov, O. (2009). Hudvil, yak skladova chastyna nematerialnykh aktyviv: Yurydychnyi zhurnal. Retrieved from http://www.justinian.com.ua/article.php?id=3217 (in Ukrainian).

18. Previous country reptrak reports. (2016). Retrieved from https://www.reputationinstitute. com/thought-leadership/country-reptrak (in English).

19. Past City RepTrak ${ }^{\circledR}$ Results. (2016). Retrieved from https://www.reputationinstitute.com/research/City-RepTrak.aspx (in English). 
20. Doing Business. (2017). Retrieved from http://www.doingbusiness.org/reports/global-reports/ doing-business-2017 (in English).

21. Index of Economic Freedom. (2017). Retrieved from http://www.heritage.org/index/ranking (in English).

22. The Global Enabling Trade Index. (2016). Retrieved from https://www.weforum.org/reports (in English).

23. The Rule of Law Index. (2016). Retrieved from https://worldjusticeproject.org/our-work/wjprule-law-index (in English).

24. The Corruption Perceptions Index 2016. Retrieved from https://www.transparency.org/news/ feature/corruption_perceptions_index_2016 (in English).

25. Posle krizisa sobstvenniki bolshogo biznesa silnee vovlecheny $\mathrm{v}$ operatcionnuiu deiatelnost kompanii — glava PwC: delo.ua. (2016). Retrieved from https://delo.ua/business/posle-krizisa-sobstvenniki-bolshogo-biznesa-silnee-vovlecheny-v-326478/?supdated_new= 1495731568 (in Russian).

26. Imidzh Ukrainy v sviti duzhe spotvorenyi — holova Amerykanskoi torhovoi palaty: delo.ua. (2016). Retrieved from https://delo.ua/business/v-ukrajini-zminjujetsja-stavlennja-do-biznesu-golova-amerikansko-327602/?supdated_new=1495731567 (in Ukrainian).

27. Iz reputatcii otdelnykh kompanii skladyvaetsia reputatciia strany — glava MFK v Ukraine: delo.ua. (2016). Retrieved from https://delo.ua/business/iz-reputacij-otdelnyh-kompanij-skladyvaetsja-reputacija-strany-326172/?supdated_new=1496754960 (in Russian).

28. Chem krupnee biznes, tem silnee ego potrebnost v polozhitelnoi reputatcii, — predstavitel ICU Aleksandr Martynenko: delo.ua. (2016). Retrieved from https://delo.ua/business/aleksandr-martynenko-326458/?supdated_new=1495585822 (in Russian).

29. Esli my sozdadim usloviia dlia vnutrennikh investorov, vneshnie pridut sami — prezident TPP: delo.ua. (2016). Retrieved from https://delo.ua/business/ni-odna-agrarnaja-strana-ne-stanovilas-konkurentosposobnoj-gen-326620/?supdated_new=1496754612 (in Russian).

doi: $10.32403 / 0554-4866-2018-2-76-76-88$

\title{
РЕПУТАЦЙНИЙ КАПІТАЛ ЯК ФАКТОР ПІДВИЩЕННЯ КОНКУРЕНТОСПРОМОЖНОСТІ УКРАЇНСЬКИХ ПІДПРИЕМСТВ НА МІЖНАРОДНОМУ РИНКУ
}

\author{
О. О. Балюн, С. Б. Фіялка \\ Національний технічний університет Украӥни \\ «Київський політехнічний інститут імені Ігоря Сікорського», \\ вул. Янгеля, 1/37, Київ, 03056, Україна \\ o.baliun@gmail.com,fryalka@i.ua
}

В умовах сучасної ринкової економіки ділова репутація стає ключовим фактором конкурентоспроможності бізнесу та найбільш дієвим засобом просування, залучення інвестицій та клієнтів. У статті доведено, щүо на ичей час в Украйні 
на державному рівні репутація не розглядається в якості стратегічного ресурсу формування довіри до держави як серед внутрішньої так $i$ зовнішньої иільових аудиторій. В результаті дослідження визначено негативні чинники, які впливають на репутацію як держави, так і украӥнських підприємств. Проведений аналіз показав взаємовплив та взаємозв'язок репутації держави та окремо взятого підприємства. Запропоновано, щзо основою впровадження нової економічної парадигми в Україні має стати формування репутаційної економіки. Репутаційний капітал повинен бути головним активом у формуванні конкурентних переваг українського бізнесу на міжнародному ринку.

Ключові слова: репутачія, ділова репутація, державне управління, інвестиичї, конкурентоздатність, рейтинги.

Стаття надійшла до редакиії 03.08.2018. Received 03.08.2018. 